\title{
PROTOTYPE OF FEEDING CONTROL SYSTEM, AUTOMATIC HARVEST USING BLYNK APPLICATION BASED ON ARDUINO UNO R3 MICROCONTROLLER AND NODEMCU
}

\author{
Yani PRABOWO ${ }^{*}$, Gatot PURWANTO ${ }^{2}$, and Alven Harun NUDIN ${ }^{3}$ \\ ${ }^{1}$ Faculty of Information Technology, Budi Luhur University, Indonesia \\ ${ }^{2-3}$ Faculty of Information Technology, Budi Luhur University, Indonesia \\ *yani.prabowo@budiluhur.ac.id
}

\begin{abstract}
Nila is a fish that is quite in demand. This fish is widely cultivated by the people of Indonesia, but the cultivation technique still uses traditional methods. The demand for high-protein fish makes farmers have to think about the best way to produce as much fish as possible. Factors to consider are feed, environmental quality and harvesting process. In the care of value fish, it is necessary to have a process of feeding fish. The distribution of feed must be given evenly so that the growth of fish is evenly distributed. The $\mathrm{pH}$ level in fish maintenance must be considered so that fish. In terms of harvesting usually requires a lot of manpower, in this study an automatic system for harvesting fish is made. With the help of microcontroller and telecommunications technology can be applied in the cultivation process. Arduino is used as the main processor using two microcontrollers, namely Arduino UNO and NodeMCU directly integrated into smartphones, which makes it easy for farmers to control the quality of their livestock products. Two microcontrollers connected by serial communication. The Blynk application as a user interface for monitoring and controlling so that this tool can make farmers not spend a lot of energy farming process.
\end{abstract}

Keywords: Arduino, NodeMCU, blynk, pH, Nila

\section{BACKGROUND}

One of the primary needs of living things is food. One of them is tilapia cultivation. Economically, tilapia cultivation is very profitable and also very supportive for the fulfillment of community nutrition. In line with the increasing public awareness of the benefits of fish, the level of demand for meat is increasing. Fish have nutrients as a source of protein and essential micronutrients to achieve good balanced nutrition and for health. Fish maintenance is generally still done traditionally and manually, especially in feeding, so often the amount of feed given is not proportional to the number of fish in the pond, so that the feed will be wasted in the bottom of the pond and will be toxic to the tie. The speed of fish growth rate is strongly influenced by the type and quality of the feed provided and the conditions of its environment. If the feed provided is of good quality, sufficient quantity and supportive environmental conditions, it is certain that the growth rate of fish will be fast as expected. On the other hand, if the feed provided is of poor quality, the quantity is insufficient and the environmental conditions are not supportive, it is certain that fish growth will be hampered (Vita, 2017). which results in sporadic schedules and sizes making the difference between feedings. Feeding planning must be appropriate so that the fish can grow rapidly and progressively according to expectations. Irregular feeding of fish will have an impact on growth and production of the resulting fish, in addition to delays in feeding can trigger cannibalism in catfish. (Khabib et, All, 2019). Preventive action to solve problems One of them is the provision of scheduled fish feed it is not yet connected to the network so it still uses the timer function for feeding. (Zaelani, et al., 2019). Another research is the Automatic Feeding and Monitoring System in Catfish Cultivation Based on the Internet of Things (Mega, et al., 2020; Prabowo, et al., 2020). can also be done using a microcontroller and internet network in feeding, in this research is the design of the application of blynk for fish rearing with an arduino microcontroller and an Mcu node that can be controlled remotely and can be made easily. A smart home is an Internet of Thing (IOT) innovation, where all objects or everyday home furnishings that are familiar to the community are "optimized" due to the integration of technology in the form of a versatile chip. items that can be found in most people's homes.

The application of this Internet of Thing-based smart home system uses the NodeMCU ESP8266 module as a microcontroller and the Blynk android application as a controlling or monitoring tool (Artiyasa, et al., 2021). The problem in this study is whether the blynk application based on Arduino and NodeMcu microcontrollers can be applied to tilapia cultivation. Internet of Things that can be applied as a remote controller with an internet network that can be applied to electronic equipment such as lights. The device can be accessed with internet services through the Blynk application so that it can eliminate the need to be in a location to activate or deactivate the device (Setiawan, 2020). Microcontrollers are inexpensive single-chip computers. Single-chip computers mean that the entire computer system lies within the confines of the integrated circuit chip. The microcontroller is capable of storing and executing programs (the most important feature). The microcontroller contains the CPU (Central Processing Unit), RAM (Random Access Memory), ROM (Read Only Memory), I/O (Input/Output) lines, serial parallel ports, timers, and sometimes other built-in peripherals such as converters. A/D (Analog-to-Digital) and D/A (Digital-to-Analog). Arduino is a microcontroller that has an Atmel AVR processor. The term Arduino can be divided into two systems, namely hardware and 
software. With an open source system, both in hardware and software, it can provide quite a lot of inspiration in the design of electronic systems. Microcontrollers from the ATMEL family are the core of Arduino processors, such as ATmega8, ATmega2560, etc. (Arisandi \& Lapan, 2014). NodeMcu is an open source IoT platform and development kit that uses the Broad programming language to help programmers create prototypes of IoT products or can use sketches with the Arduino IDE. This development kit is based on the ESP8266 module, which integrates GPIO, PWM (Pulse Width Modulation), IIC, 1-Wire and ADC (Analog to Digital Converter) all in one board. The uniqueness of Nodemcu itself is a very small board, which is $4.83 \mathrm{~cm}$ long, $2.54 \mathrm{~cm}$ wide, and weighs 7 grams. But despite its small size, this board is equipped with wifi features and open source firmware. The use of NodeMcu is more profitable in terms of cost and space efficiency, because NodeMcu which is small in size, is more practical and the price is much cheaper than Arduino Uno (Santoso, et al., 2021)

\section{METHODS}

System Design In designing this system, it consists of 2 parts, namely hardware design (hardware) and software design (software). This study uses Arduino as the main component to read sensors and move the actuator, Node $\mathrm{MCu}$ is used as the overall system controller, Arduino is connected to $\mathrm{pH}$ sensors, ultrasonic sensors, $\mathrm{dc}$ and stepper motor drivers, also connected to NodeMCu as a communication gateway and then displays as a viewer data on the system.

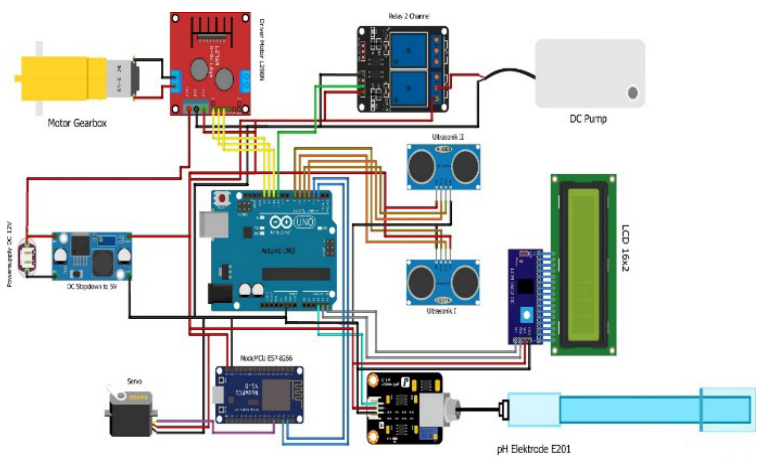

Picture 1. System design architecture

The input system consists of a $\mathrm{pH}$ sensor, 2 ultrasonic sensors, an Arduino UNO data processing unit, the NodeMCU functions as a communication line between the Arduino and the user via a cellular phone, the output system consists of a diver motor, a relay pump and an LCD as a data display in the system. A pool with a size of $15 \times 15 \mathrm{~cm}$ which is made in such a way to resemble a real pond. Making fish harvesting machines using paralon and acrylic that are shaped in such a way to get the best way of working. Arduino Uno as a microcontroller for driving a lot of hardware communicates with the NodeMCU ESP8266 as a connecting tool to the smartphone network and the Blynk application. Input data obtained through the $\mathrm{pH}$ sensor. As a pH meter, an indicator of the quality of the $\mathrm{pH}$ of the water in the pond and ultrasonic sensor I as an indicator of residual fish feed and ultrasonic sensor II as an indicator of the remaining liquid $\mathrm{pH}$ stabilizing pond water. When the distance detected by the ultrasonic sensor I in the remaining feed exceeds the specified limit $(10 \mathrm{~cm})$, it will send a warning notification in the form of a pop-up notification on the Blynk application to fill the feed holder.

Likewise ultrasonic II. The $\mathrm{pH}$ meter will detect the $\mathrm{pH}$ quality of the water. If the $\mathrm{pH}$ of the water touches the numbers $<6.5$ and $>8.0$, a pop-up notification will appear indicating that it should be immediately lowered/increased by providing a $\mathrm{pH}$ stabilizer. Explanation Drawn in Figure 1 and Figure 2 flowchart system. The tool design diagram below:

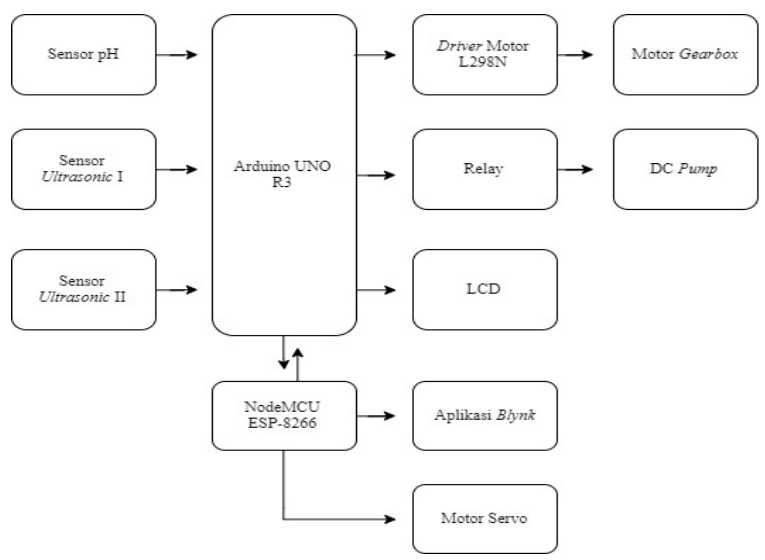

Figure 1. System block diagram

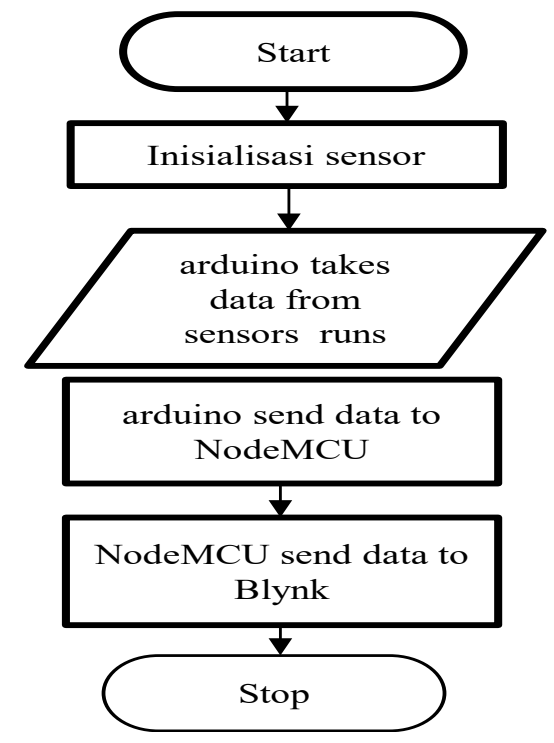

Figure 2. Flowchart System

\section{Blynk Application Design}

Blynk is a mobile OS application used for Android and iOS that functions as a controller for Arduino, or other microcontrollers. In this study, the Blynk application is used as an Arduino microcontroller control via the existing internet network. The Blynk application itself is used to control and monitor remotely, the microcontroller must be connected to the internet network and a good internet connection. 


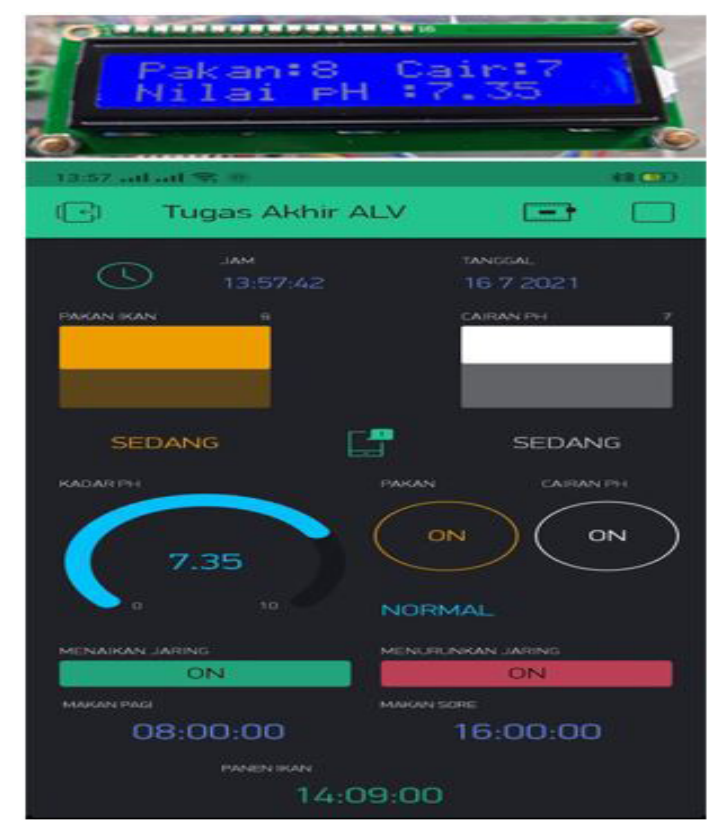

Picture 2. Application display

\section{RESULTS AND DISCUSSION \\ Sensor PH}

Testing of the $\mathrm{pH}$ sensor will be carried out by comparing the $\mathrm{pH}$ received by the sensor with the value of a known $\mathrm{pH}$ powder. After obtaining the value of the $\mathrm{ADC}$ and Voltage of each $\mathrm{pH}$ liquid, a formula can be made to obtain the $\mathrm{pH}$ value that is used as a reading on the $\mathrm{pH}$ sensor. In the formula here, it is enough to take data from low and high liquid voltages, namely as a reference for measurement, the $\mathrm{pH}$ value is converted into a voltage value that is understood by the microcontroller.

Table 1. pH Electrode Characteristics

\begin{tabular}{cc}
\hline $\mathrm{pH}$ Electrode & Characteristics \\
\hline Voltage $(\mathrm{mV})$ & $\mathrm{pH}$ Value \\
414.12 & 0.00 \\
354.96 & 1.00 \\
295.80 & 2.00 \\
236.64 & 3.00 \\
177.48 & 4.00 \\
118.32 & 5.00 \\
59.16 & 6.00 \\
0.00 & 7.00 \\
\hline
\end{tabular}

\section{Sensor Ultrasonic}

Ultrasonic sensor testing is done by comparing the distance obtained by the sensor with measurements made by researchers using a ruler as a tool. The program below is a command snippet where the object distance reading process by two ultrasonic sensors. The ultrasonic sensor in this tool is used as an indicator of the amount of remaining feed and liquid in the container. The data will be displayed on the LCD based on the value read by the sensor, table 2 ultrasonic sensor readings. The distance value on the tool has been set as an indicator of the remaining feed and liquid by giving a value if the object is getting closer to the ultrasonic sensor $(0 \mathrm{~cm})$ it is assumed that the fish feed and liquid are full. Conversely, if the object is further away from the ultrasonic sensor, it is assumed that the fish feed and liquid will run out. The distance data that has been set as an indicator can be seen in the table below

Table 2. Ultrasonic Sensor Reading

\begin{tabular}{|c|c|c|}
\hline No & Distance on Ultrasonic Sensor & Result \\
\hline & $0-5 \mathrm{~cm}$ & empty \\
\hline & $6-9 \mathrm{~cm}$ & full \\
\hline & $>10$ & full \\
\hline
\end{tabular}

\section{Pump Relay Testing}

The program below is a process which initializes the relay which is used as an automatic switch from the DC pump which is used to provide $\mathrm{pH}$ stabilizing fluid in the pool water, below to activate the pump in Picture 3 .

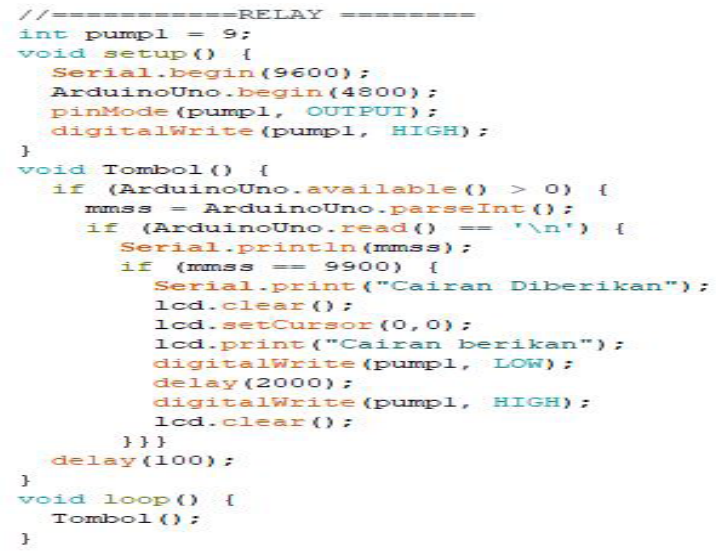

Picture 3. Sourcecode to activate pump

\section{Acceptance of the Liquid Button Controlling Feature when Clicked from the Blynk Application}

The program below is a snippet of the process of receiving commands sent from the Blynk Application. The process shows that if there is an incoming data value of 9900 (Liquid Button) from the NodeMCU via serial communication, the Relay command will be executed with a value of LOW and the DC Pump turns on by providing $\mathrm{pH}$ stabilizing liquid for 2 seconds, shown in Picture 4.

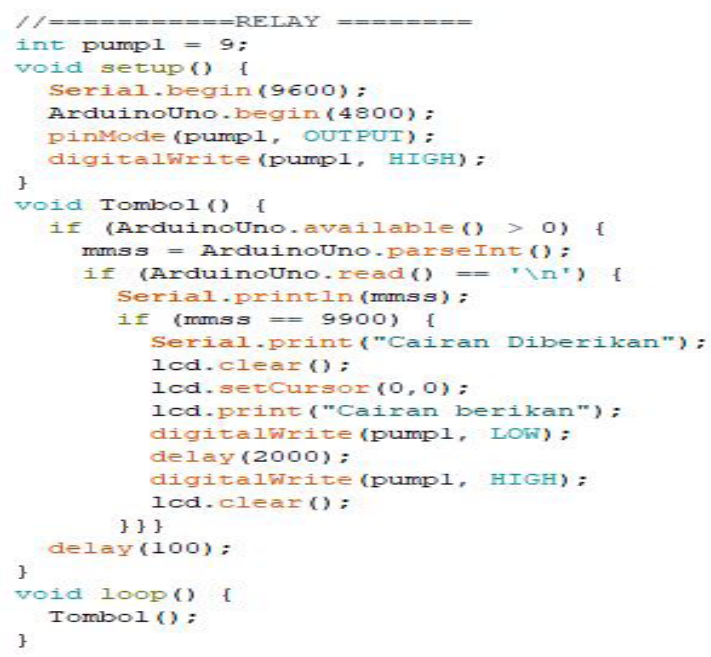

Picture 4. Sourcecode to controlling liquid button 
Acceptance of Controlling Features The Button Raises or Lowers The Net If It Is Clicked from The Blynk App

The program below is a snippet of the process of receiving commands sent from the Blynk Application. The process shows that if there is an incoming data value of 7000 (Network Lowering Button) from the NodeMCU via serial communication, a command will be executed for the motor driver to rotate the DC motor counterclockwise to lower the net, shown in Picture 5.

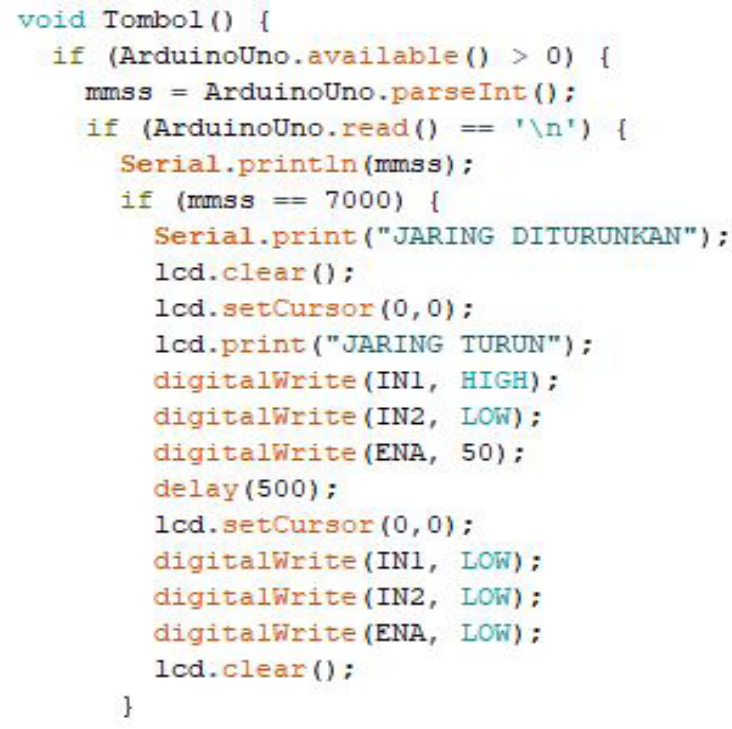

Picture 5. Sourcecode to down the net in blynk

On the other hand, if there is an incoming data value of 8000 (Network Raising Button), then a command will be executed for the motor driver to rotate the DC motor clockwise to raise the net. , shown in Picture 6.

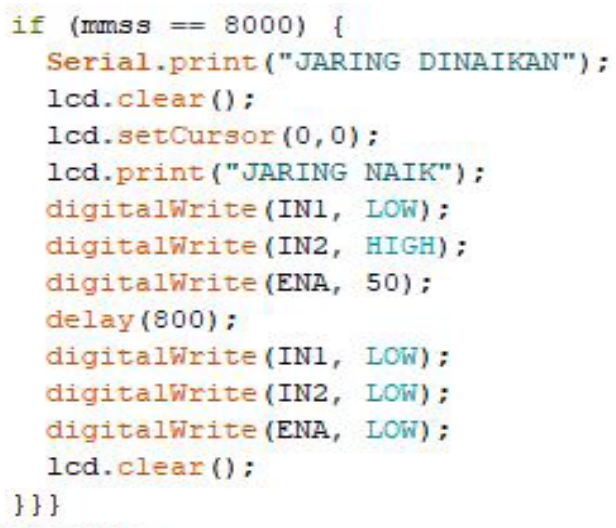

Picture 6. Sourcecode to raise the net

Acceptance of Controlling Features The Button Raises or Lowers The Net If It Is Clicked from The Blynk App.

The program below is a snippet of the process of receiving commands sent from the Blynk Application. The process shows that if there is an incoming data value of 7000 (Network Lowering Button) from the NodeMCU via serial communication, a command will be executed for the motor driver to rotate the DC motor counterclockwise to lower the net. , shown in Picture 7.

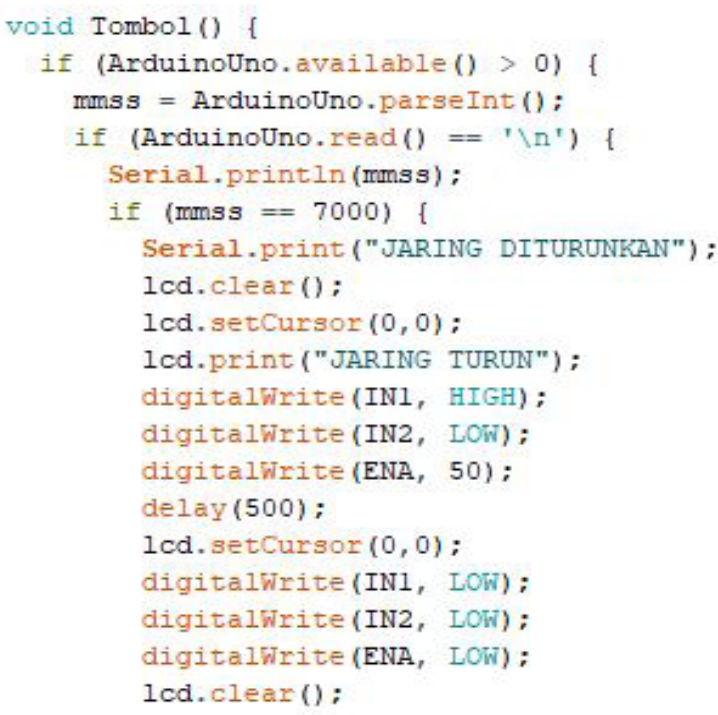

Picture 7. source code to raise the net in arduino

On the other hand, if there is an incoming data value of 8000 (Network Raising Button), then a command will be executed for the motor driver to rotate the DC motor clockwise to raise the net.

\section{Servo Motor Testing}

Testing of servo motors that feed fish. Testing based on the degree of rotation according to the theory of the servo motor itself $\left(0-180^{\circ}\right)$. Below is a program for testing servo motors. Testing of servo motors that feed fish. Testing based on the degree of rotation according to the theory of the servo motor itself $\left(0-180^{\circ}\right)$. Based on the above program get the results in table 3 and table 4 below:

Table 3. Servo Motor Testing

\begin{tabular}{cc}
\hline Servo & Information \\
\hline $0^{\circ}$ & good \\
$90^{\circ}$ & good \\
$120^{\circ}$ & good \\
$180^{\circ}$ & good \\
\hline
\end{tabular}

Table 4. Servo Motor Testing Based on a Predefined Time (Timer)

\begin{tabular}{lccc}
\hline No & Set time & Status & Result \\
\hline 1 & $08: 00$ & Morning feed & Open \\
2 & $16: 00$ & Afternoon feed & Open \\
\hline
\end{tabular}

\section{Blynk Testing}

Synchronizes the data that appears on the LCD and the Blynk App and tests the features used on the Blynk App.. Table 5, Tests Comparing Display Data on Blynk Applications With LCD, Picture 8 comparison display of blynk and LCD applications, Picture 9 Overall system view. 
Table 5. Tests Comparing Display Data on Blynk Applications With LCD

\begin{tabular}{llcc}
\hline No & Detail & $\begin{array}{c}\text { On Blynk } \\
\text { Application }\end{array}$ & On LCD \\
\hline 1 & pH Quality in Water & 7.35 & 7.35 \\
2 & Leftover Fish Feed & 8 & 8 \\
3 & Residual Liquid $\mathrm{pH}$ & 7 & 7 \\
\hline
\end{tabular}

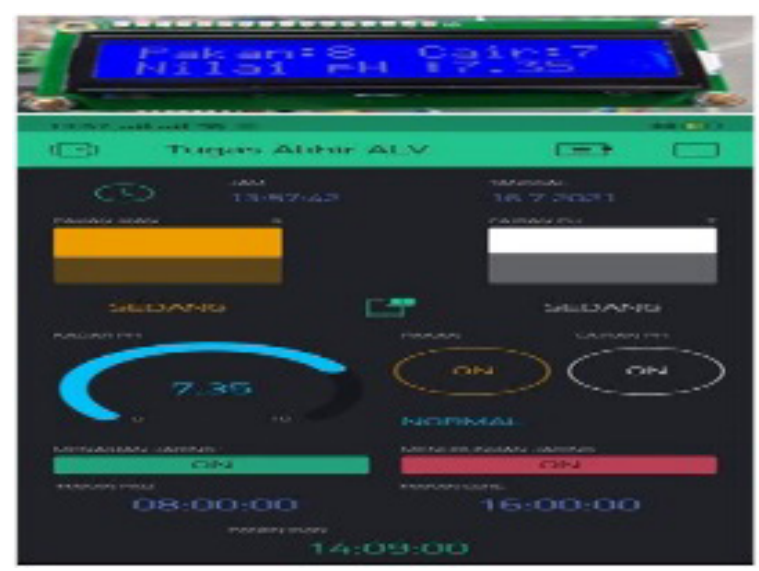

Picture 8. Comparison display of blynk and LCD applications

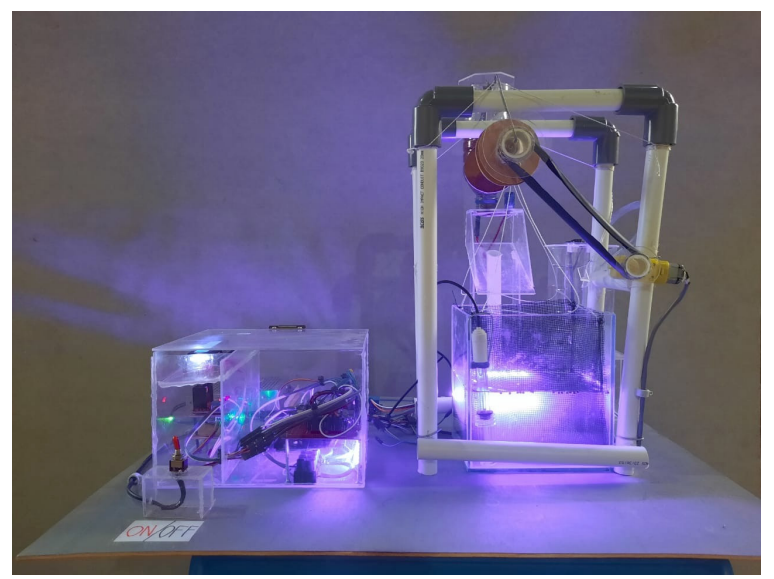

Picture 9. Overall system view

\section{CONCLUSION}

Based on the planning, manufacture, testing and discussion of this tool, conclusions can be drawn:

1. This tool can provide its own feed by pressing the widget on the Blynk Application or based on a predetermined time. Therefore, this tool can reduce the labor of farmers in direct feeding.

2. The tool can notify the $\mathrm{pH}$ level in the water if it is in NORMAL conditions on the smartphone via the Blynk Application.

3. Can harvest by simply pressing the widget on the Blynk Application and if you want it to be set automatically by determining the time of harvesting fish, you can input the desired time. Breeders no longer need to spend energy to harvest it directly.

\section{REFERENCES}

Arisandi, ED., \& Lapan, P. (2014). Kemudahan Pemrograman Mikrokontroller Arduino Pada Aplikasi Wahana Terbang. Jurnal SETRUM, 3(2), 3-6.

Artiyasa, M., et all. (2021). Aplikasi Smart Home Node MCU Iot Untuk Blynk. Jurnal Rekayasa Teknologi Nusa Putra, 7(1), 1-7. https://doi.org/10.52005/ rekayasa.v7i1.59

Mega, C., Kurniawan, A., Sahertian, J., Sanjaya, A., Seminar Nasional Inovasi Teknologi UN PGRI Kediri, 25 Juli 2020, e-ISSN: 2549-7952 p-ISSN: 2580-3336 . Sistem Monitoring dan Pemberian Pakan Otomatis pada Budidaya Ikan Lele Berbasis Internet of Things. 224-228.

Prabowo, RR., Kusnadi, K., \& Subagio, RT. (2020). Sistem Monitoring dan Pemberian Pakan Otomatis Pada Budidaya Ikan Menggunakan Wemos dengan Konsep Internet of Things (IoT). Jurnal Digit, 10(2), hal 185-195. https://doi.org/10.51920/jd.v10i2.169

Santoso, I., Adiwisastra, MF., Simpony, BK., Supriadi, D., \& Purnia, DS. (2021). Implementasi NodeMCU dalam Home Automation dengan Sistem Kontrol Aplikasi Blynk. Swabumi, 9(1), 32-40. https://doi. org/10.31294/swabumi.v9i1.10459

Setiawan, R. (2020). Rancang Bangun Alat Pemberi Pakan Ikan Menggunakan Mikrokontroler. Journal ICTEE, 1(1), 51-54. https://doi.org/10.33365/jictee.v1i1.698

Vita, Y. (2017). Pengaruh Pemberian Jenis Pakan Yang Berbeda Terhadap Laju Pertumbuhan Benih Ikan Nila (Oreochiomis Niloticus) Dan Kualitas Air Di Akuarium Pemeliharaan. Journal of Chemical Information and Modeling, 42(2), 91-99.

Khabib Yahya Nashrullah, Moh. Bhanu Setyawan, Adi Fajaryanto C Jurnal Ilmiah Mahasiswa Rancang Bangun Iot Smart Fish Farm Dengan Kendali Raspberry Pi Dan Webcam, Url: http://studentjournal. umpo.ac.id/index.php/komputek/, hal 81-91

Zaelani, A., Nugraha, DA., \& Wiguna, AS. (2019). Rancang Bangun Alat Penyebar Pakan Secara Maksimal Pada Mesin Pemberi Makan Otomatis Ikan Lele. RAINSTEK: Jurnal Terapan Sains \& Teknologi, 1(4), 1-10. https://doi.org/10.21067/jtst.v1i4.4088 